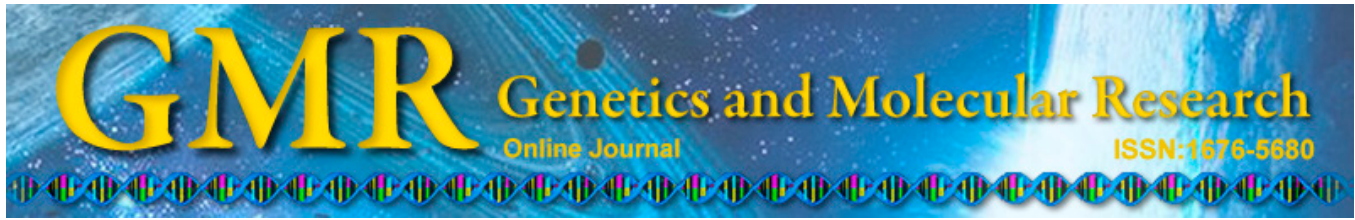

\title{
Association of $T L R 2$ and $T L R 4$ non-missense single nucleotide polymorphisms with type 2 diabetes risk in a southern Chinese population: a case-control study
}

\author{
W.H. Huang ${ }^{1 *}$, L.H. Nie ${ }^{5 *}$, L.J. Zhang ${ }^{1}$, L.P. Jing ${ }^{1}$, F. Dong ${ }^{1}$, M. Wang ${ }^{1}$,

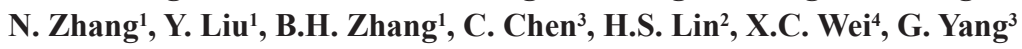 \\ and C.X. Jing ${ }^{1}$ \\ ${ }^{1}$ Department of Epidemiology, School of Medicine, Jinan University, \\ Guangzhou, Guangdong, China \\ ${ }^{2}$ Department of Statistics, School of Medicine, Jinan University, Guangzhou, \\ Guangdong, China \\ ${ }^{3}$ Department of Parasitology, School of Medicine, Jinan University, \\ Guangzhou, Guangdong, China \\ ${ }^{4}$ Family Planning Research Institute of Guangdong, Guangzhou, Guangdong, \\ China \\ ${ }^{5}$ Department of Endocrinology, The First Affiliated Hospital of Jinan University, \\ Guangzhou, Guangdong, China \\ *These authors contributed equally to this study. \\ Corresponding author: C.X. Jing \\ E-mail: jcxphd@gmail.com
}

Genet. Mol. Res. 14 (3): 8694-8705 (2015)

Received October 21, 2014

Accepted April 17, 2015

Published July 31, 2015

DOI http://dx.doi.org/10.4238/2015.July.31.18

\begin{abstract}
Toll-like receptors (TLRs), the triggers of the innate and adaptive immune responses, are involved in the pathogenesis of type 2 diabetes mellitus (T2DM). Several studies have investigated the effects of genetic polymorphisms in TLR4 and TLR2, but they have yielded limited results. We investigated whether non-missense genetic
\end{abstract}


polymorphisms in the regulatory regions of TLR4 and TLR2 were related to T2DM in a southern Chinese population. Single nucleotide polymorphisms (SNPs) in TLR4 (rs1927911, rs11536889, rs1927907, rs1927906, rs1927914, rs7873784, and rs2149356) and TLR2 (rs1898830, rs3804099, rs4696480, and rs3804100) were genotyped in 552 T2DM and 552 unrelated age- and gender-matched controls by SNaPShot Multiplex assay. Genotypes GG $(\mathrm{OR}=0.09,95 \% \mathrm{CI}=0.01$ $0.83, \mathrm{P}=0.03)$ and $\mathrm{CG}(\mathrm{OR}=0.08,95 \% \mathrm{CI}=0.01-0.74, \mathrm{P}=0.03)$ of the 3'-untranslated region (UTR) SNP rs7873784 in TLR4, and genotype $\mathrm{AG}(\mathrm{OR}=0.67,95 \% \mathrm{CI}=0.46-0.97, \mathrm{P}=0.04)$ and allele $\mathrm{G}(\mathrm{OR}=$ $0.88,95 \% \mathrm{CI}=0.79-0.97, \mathrm{P}=0.01)$ of the intron SNP rs 1898830 in TLR2 were identified as protective against the development of T2DM in southern Chinese people. In contrast, a meta-analysis of rs1927911 and rs1927914 showed no association. Haplotypes AGTT $(\mathrm{OR}=0.34$, $95 \% \mathrm{CI}=0.15-0.77, \mathrm{P}=0.01)$ and AATT $(\mathrm{OR}=1.20,95 \% \mathrm{CI}=1.01$ $1.44, \mathrm{P}=0.05)$ in $T L R 2$ were significantly associated with susceptibility to T2DM. Our results suggest that the effects of non-missense polymorphisms located in the regulatory regions of TLR4 and TLR2 should not be neglected in T2DM association analysis.

Key words: Toll-like receptor 4; Toll-like receptor 2; Type 2 diabetes; Non-missense single nucleotide polymorphisms; Chinese

\section{INTRODUCTION}

Type 2 diabetes mellitus (T2DM) is a metabolic disorder that is characterized by high blood glucose in the context of insulin resistance and relative insulin deficiency (Kumar et al., 2005). As of 2010, it was estimated that there were 285 million patients globally with T2DM, making up about $90 \%$ of diabetes cases. In China, diabetes has become a major public health problem. The age-standardized prevalence of total diabetes and pre-diabetes are 9.7 and $15.5 \%$, respectively, accounting for 92.4 million adults with diabetes and 148.2 million adults with pre-diabetes (Yang et al., 2010).

Chronic low-grade inflammation and activation of the innate immune system have been implicated in the pathogenesis and prediction of T2DM and associated complications (Pickup, 2004). Toll-like receptors (TLRs) are among the most important components of the innate immunity pathway. TLRs that start a signaling pathway through the nuclear factor kappa $\mathrm{b}(\mathrm{NF}-\mathrm{kB})$ could have an impact on the development or progression of diabetes (Wong and Wen, 2008).

Interestingly, the expression levels of TLR2, TLR4, MyD88, phosphorylated IRAK-1, Trif, TICAM-1, IRF-3, and NF-kB p65 are increased in obese subjects (Creely et al., 2007) and T2DM subjects (Dasu et al., 2010). The probable cause is that the increasing levels of various biochemical factors, including endotoxins (lipopolysaccharides), fatty acids, etc., which appear in obese people, are thought to increase the activation of TLR2 and TLR4 (Miller et al., 2005; Park et al., 2006). In addition, obesity is always accompanied by high blood glucose, which induces the expression of TLR2 in human monocytes (Dasu et al., 2008). Activated TLR2 and TLR4 mediate the inflammatory response through MyD88 signaling, which in- 
creases the release of various pro-inflammatory factors (IL-6, TNF- $\alpha$, IL-1 $\beta$, etc.), resulting in the agglomeration of inflammatory cells (Yang et al., 2008). Ultimately, a microenvironment of inflammation in local tissues exacerbates $\beta$-cell dysfunction (Yin et al., 2014), insulin resistance, and progression to T2DM (Hotamisligil 2006; Donath and Shoelson, 2011). This has been proven in a mouse model in which inhibition of TLR2 expression dramatically improved insulin sensitivity (Caricilli et al., 2008; Kuo et al., 2011).

Moreover, evidence suggests that genetic variations in the TLR4 gene greatly influence immune responses towards pathogenic challenges and disease outcomes (Noreen et al., 2012), although most of these studies have been restricted to two missense polymorphisms, Asp299Gly and Thr399Ile, in the TLR4 gene. The alleles 299Gly and 399Ile are associated with a lower prevalence of T2DM (Bagarolli et al., 2010). However, in the Augsburg Region there was no association between Asp299Gly and T2DM (Illig et al., 2003). The Asp299Gly polymorphism of the TLR4 gene is associated with early-onset diabetic retinopathy in T2DM patients, and the G allele of Asp299Gly is an independent risk factor for early-onset diabetic retinopathy (Buraczynska et al., 2009). Recently, it has been reported that TLR4 $+3725 \mathrm{G} / \mathrm{C}$ and $+11367 \mathrm{G} / \mathrm{C}$ polymorphisms may be novel protective factors against T2DM in the Chinese population (Jiang et al., 2013). However, only a few studies have focused on the effect of TLR2 polymorphisms in the progression of T2DM. Maldonado-Bernal et al. (2011) found that the TLR2 polymorphism (R753Q) failed to play a major role in the progress of T2DM in a Mexican population. Additionally, Liu et al. (2012) found no statistically significant difference between TLR2 polymorphisms (Arg677Trp and Arg753Gln) and the risk of T2DM in Chinese subjects. The single nucleotide polymorphisms (SNPs) located in regulatory regions, such as the 5'-untranslated region (UTR), where the promoter or transcription factor binding sites are located, and the 3'-UTR, which may influence the expression of mRNAs, should be regarded as important SNPs owing to their potential influence on disease susceptibility. Overall, evidence that demonstrates the effects of TLR2 and TLR4 gene polymorphisms on T2DM is still limited.

Therefore, the aim of the present study was to determine whether TLR4 and TLR2 are associated with T2DM in a southern Chinese population. We evaluated the association between seven SNPs (rs1927911, rs11536889, rs1927907, rs1927906, rs1927914, rs7873784, and rs2149356) situated in the 3'-UTR, introns, 5'-UTR, and transcriptional regions of the TLR4 gene, and four SNPs (rs1898830, rs3804099, rs4696480, and rs3804100) situated in the intron and coding-synon in TLR2, and T2DM in a Chinese population.

\section{MATERIAL AND METHODS}

\section{Study subjects and laboratory analysis methods}

This case-control study included 552 Chinese patients diagnosed with T2DM according to the 2003 American Diabetes Association criteria (Genuth et al., 2003). They were sequentially recruited from The First Affiliated Hospital of Jinan University between September 2011 and January 2013 in Guangzhou, China. The healthy controls $(\mathrm{N}=552)$ were volunteers with normal fasting glucose and no family history of diabetes recruited during the same period and matched with the T2DM patients by gender and age ( \pm 5 years). All individuals involved in this study were unrelated Chinese adults. Written informed consent was obtained from all 
subjects. The Jinan University Ethics Committee approved the study protocol. Weight and height were measured to calculate body mass index (BMI). All patients studied were evaluated by medical doctors. A venous blood specimen $(5 \mathrm{~mL})$ was collected from each participant using a vacuum tube containing ethylenediaminetetraacetic acid anticoagulation and stored at $-85^{\circ} \mathrm{C}$ until required. The genomic DNA from the peripheral blood of each subject was obtained using a QIAamp DNA kit (Qiagen, Hilden, Germany). The quality and quantity of DNA were checked using a NanoDrop spectrophotometer (Thermo Fisher, Wilmington, DE, USA). DNA samples were amplified using an ABI GeneAmp ${ }^{\circledR} 9700$ Dual 384 machine, and mass spectrometry was carried out by matrix-assisted laser desorption/ionization time-of-flight.

\section{SNP selection}

The SNPs were selected from The International HapMap website (http://hapmap. ncbi.nlm.nih.gov) using genotype data from the Han Chinese in Beijing, China, and the National Center for Biotechnology Information SNP database, providing they met the following criteria: a) R-square cut-off $>0.8$; b) minor allele frequency of SNP $>0.05$; and c) Hardy-Weinberg equilibrium (HWE) P value cut-off $>0.001$. We then combined the data from the National Center for Biotechnology Information website with the results of a literature review of the public database. This strategy identified seven SNPs in the TLR4 gene (rs1927911, rs11536889, rs1927907, rs1927906, rs1927914, rs7873784, and rs2149356) and four SNPs in TLR2 (rs1898830, rs3804099, rs4696480, and rs3804100). Detailed information about these SNPs (alleles, gene position, and minor allele frequency) is summarized in Table 1 .

\begin{tabular}{|c|c|c|c|c|c|c|c|}
\hline Gene & dbSNP ID & Chrom. Pos & SNP location & Alleles & MAF (\%) & HWE P value* & Call rate $(\%)$ \\
\hline \multirow[t]{7}{*}{ TLR4 } & rs1927914 & 120464725 & 5'-near gene & $\mathrm{C} / \mathrm{T}$ & 36.8 & 0.892 & 99.9 \\
\hline & rs1927911 & 120470054 & Intron & $\mathrm{C} / \mathrm{T}$ & 36.8 & 0.921 & 100 \\
\hline & rs1927907 & 120472764 & Intron & $\mathrm{A} / \mathrm{G}$ & 22.2 & 0.970 & 99.0 \\
\hline & rs2149356 & 120474199 & Intron & $\mathrm{A} / \mathrm{C}$ & 36.8 & 0.905 & 99.3 \\
\hline & rs11536889 & 120478131 & 3'-UTR & $\mathrm{C} / \mathrm{G}$ & 25.0 & 0.209 & 99.3 \\
\hline & rs7873784 & 120478936 & 3'-UTR & $\mathrm{C} / \mathrm{G}$ & 10.2 & 0.626 & 99.4 \\
\hline & rs1927906 & 120480115 & 3'-near gene & $\mathrm{A} / \mathrm{G}$ & 5.9 & 0.689 & 99.9 \\
\hline \multirow{4}{*}{$T L R 2$} & rs1898830 & 154608453 & Intron & $\mathrm{A} / \mathrm{G}$ & 47.0 & 0.521 & 93.3 \\
\hline & rs3804099 & 154624656 & Coding-synon & $\mathrm{T} / \mathrm{C}$ & 27.0 & 0.149 & 98.2 \\
\hline & rs4696480 & 154607126 & Intron & $\mathrm{A} / \mathrm{T}$ & 44.0 & 0.270 & 98.7 \\
\hline & rs3804100 & 154625409 & Coding-synon & $\mathrm{C} / \mathrm{T}$ & 24.0 & 0.397 & 99.8 \\
\hline
\end{tabular}

$\mathrm{dbSNP}=$ database single nucleotide polymorphism; MAF $=$ minor allele frequency, HWE $=$ Hardy-Weinberg equilibrium; UTR = untranslated region. *HWE P value cut-off: 0.001 .

\section{Genotyping assay}

The polymerase chain reaction primers are shown in Table 2. Genomic DNA (5-10 ng) was amplified in a final volume of $5 \mu \mathrm{L}$ as follows: initial denaturation at $94^{\circ} \mathrm{C}$ for $4 \mathrm{~min}$ followed by 40 cycles at $94^{\circ} \mathrm{C}$ for $20 \mathrm{~s}$, annealing at $56^{\circ} \mathrm{C}$ for $30 \mathrm{~s}$, and extension at $72^{\circ} \mathrm{C}$ for 1 min. Shrimp alkaline phosphatase (SAP) enzyme solution $(2 \mu \mathrm{L})$ (including $0.17 \mu \mathrm{L}$ SAP buffer, $0.3 \mu \mathrm{L}$ SAP enzyme, and $1.53 \mu \mathrm{L}$ water) was added and the mixture was incubated at $37^{\circ} \mathrm{C}$ for $40 \mathrm{~min}$ and at $85^{\circ} \mathrm{C}$ for $5 \mathrm{~min}$, then stored at $4^{\circ} \mathrm{C}$. After adding $2 \mu \mathrm{L}$ High Plex iLEX 
Gold (Invitrogen, USA) reaction mixture (including $0.94 \mu \mathrm{L}$ primer mix, $0.2 \mu \mathrm{L}$ Gold buffer, $0.2 \mu \mathrm{L}$ termination mix, $0.041 \mu \mathrm{L}$ enzyme, and $0.619 \mu \mathrm{L}$ water) to each sample, we conducted a thermocycle as follows: initial denaturation at $94^{\circ} \mathrm{C}$ for $30 \mathrm{~s}$ followed by 40 cycles at $94^{\circ} \mathrm{C}$ for $5 \mathrm{~s}$, annealing at $52^{\circ} \mathrm{C}$ for $5 \mathrm{~s}$, extension at $80^{\circ} \mathrm{C}$ for $5 \mathrm{~s}$, then final extension at $72^{\circ} \mathrm{C}$ for 3 min. Finally, we acquired the spectra.

\section{Statistical analysis}

Tests were assessed using the Haploview (v.4.2) program and SAS software (v.9.3) to analyze deviation from HWE and to compare allelic frequencies between cases and controls (Barrett et al., 2005). The HWE for SNP genotypes among controls was tested using a goodness-of-fit $\chi^{2}$ test. After adjustment for potential covariates, the odds ratios ORs and 95\%CIs were calculated to assess the associations between the 11 SNPs and T2DM risk, using conditional logistic regression. The potential covariates included age, gender, and BMI. Continuous variables are reported as means \pm SD and categorical variables as numbers of cases. The statistical significance limit was set at $\mathrm{P}=0.05$. The PLINK software was used to establish a log-additive model and calculate ORs, 95\%CIs, and P values. Meta-analysis was performed using the Stata software (v.12.0) to pool the studies by Singh et al. (2013; 2014), Peng et al. (2014), and our own. The statistical power of the present study was evaluated using the Quanto software. The prevalence of T2DM was estimated at $5 \%$.

Table 2. Polymerase chain reaction primers and amplicon sizes.

\begin{tabular}{|c|c|c|c|}
\hline Gene & dbSNP ID & Primers & Amplicon size (bp) \\
\hline \multirow[t]{14}{*}{ TLR4 } & rs1927914 & F: ACGTTGGATGGTGCTTGGAGGATATTACAG & \\
\hline & & R: ACGTTGGATGGTAGCAAGTGCAATGTAAG & 125 \\
\hline & rs1927911 & F: ACGTTGGATGTCAAGATGTCCAGACCTTCC & \\
\hline & & R: ACGTTGGATGCATCACTTTGCTCAAGGGTC & 109 \\
\hline & rs1927907 & F: ACGTTGGATGGGGTATCCAGTGGATTGAAG & \\
\hline & & R: ACGTTGGATGCTATTAAGGTAGACCACCTC & 125 \\
\hline & rs2149356 & F: ACGTTGGATGTTGTTAGTTGGTAGCCAAG & \\
\hline & & R: ACGTTGGATGGAGTATCTGTGACACTTATG & 104 \\
\hline & rs11536889 & F: ACGTTGGATGGAACCCCATTAATTCCAGAC & \\
\hline & & R: ACGTTGGATGTTTCCTGTTGGGCAATGCTC & 109 \\
\hline & rs7873784 & F: ACGTTGGATGATGAGAGGTACCCTCTTAAC & \\
\hline & & R: ACGTTGGATGGCTCTAAAGATCAGCTGTAT & 108 \\
\hline & rs1927906 & F: ACGTTGGATGTGCTTGTCCACCTCACCTG & \\
\hline & & R: ACGTTGGATGCTCCTTCCTATCAGTTCCCT & 85 \\
\hline \multirow[t]{8}{*}{$T L R 2$} & rs1898830 & F: ACGTTGGATGGATCCCCTATTTTCTAGCAC & \\
\hline & & R: ACGTTGGATGTGAATGAGCAAGCAAATACC & 141 \\
\hline & rs3804099 & F: ACGTTGGATGTATGCTGCTTCATATGAAGG & \\
\hline & & R: ACGTTGGATGGATCTACAGAGCTATGAGCC & 99 \\
\hline & rs4696480 & F: ACGTTGGATGCTCACCATGTGATGCTTTCC & \\
\hline & & R: ACGTTGGATGGGGAAGTCCAAGATTGAAGG & 102 \\
\hline & rs 3804100 & F: ACGTTGGATGTTCCAGTGTCTTGGGAATGC & \\
\hline & & R: ACGTTGGATGTGCCTGAAACTTGTCAGTGG & 118 \\
\hline
\end{tabular}

$\mathrm{dbSNP}=$ database single nucleotide polymorphism; TLR $=$ toll-like receptor; $\mathrm{F}=$ forward $\mathrm{R}=$ reverse.

\section{RESULTS}

The general characteristics of the $552 \mathrm{~T} 2 \mathrm{DM}$ cases and the 552 controls are summa- 
rized in Table 3. There were no significant differences in age or gender between the T2DM patients and the healthy control group $(\mathrm{P}>0.05)$, but there was a significant difference in BMI between T2DM patients and the control group $(\mathrm{P}<0.01)$. Only 84 patients $(23.9 \%)$ did not have any complication, and at least $76.1 \%$ (268/352) of patients had complications.

Table 3. General characteristics of the study population.
\begin{tabular}{lccc}
\hline Characteristics & Case $(\mathrm{N}=552)$ & Control $(\mathrm{N}=552)$ & P value* \\
\hline Age, years (mean $\pm \mathrm{SD})$ & $62.12 \pm 13.26$ & $62.36 \pm 12.99$ & 0.754 \\
Gender & 269 & 267 & 0.904 \\
$\quad$ Male & 283 & 285 & $0.000^{*}$ \\
$\quad$ Female & $24.38 \pm 3.38$ & $21.94 \pm 2.73$ & \\
BMI $\left(\mathrm{kg} / \mathrm{m}^{2}\right)$ &
\end{tabular}

BMI $=$ body mass index. $*$ The Mann-Whitney test was used to analyze differences. $* * \mathrm{P}<0.05$.

\section{Association of TLR4 polymorphisms with T2DM}

The SNPs genotyped were in HWE $(\mathrm{P}>0.05)$. The genotype distributions of the eleven polymorphisms are shown in Table 4 . In the TLR4 gene, compared with the CC genotype of 3'-UTR SNP rs7873784, subjects with $\mathrm{GG}(\mathrm{OR}=0.09,95 \% \mathrm{CI}=0.01-0.83 ; \mathrm{P}=0.03)$ and $\mathrm{GC}(\mathrm{OR}=0.08,95 \% \mathrm{CI}=0.01-0.74 ; \mathrm{P}=0.03)$ had a lower risk of having T2DM after adjusting for the conventional risk factors such as age, gender, and BMI. In the TLR2 gene, the subjects with the heterozygote $\mathrm{AG}(\mathrm{OR}=0.67,95 \% \mathrm{CI}=0.46-0.97, \mathrm{P}=0.04)$ and the allele $\mathrm{G}(\mathrm{OR}=0.88,95 \% \mathrm{CI}=0.79-0.97, \mathrm{P}=0.01)$ in $\mathrm{SNP}$ rs 1898830 had a lower risk of having T2DM. In the log-additive model, there was a significant difference in SNP rs1898830 (OR $=0.78,95 \% \mathrm{CI}=0.67-0.95 ; \mathrm{P}=0.01)$. The genotypes of rs 1927914, rs 1927911, rs 1927907, rs2149356, rs11536889, rs1927906, rs3804099, rs4696480, and rs3804100 displayed no association with T2DM.

\section{Meta-analysis for rs1927911 and rs1927914}

The rs1927911 and rs1927914 SNPs, reported by Singh et al. $(2013,2014)$ and Peng et al. (2014), were subjected to meta-analysis to evaluate the pooled effects. The results indicated that there was high heterogeneity in rs1927911 $\left(\mathrm{I}^{2}=85.0 \%\right)$ and rs1927914 $\left(\mathrm{I}^{2}=61.0 \%\right)$, and the overall effect of $\mathrm{rs} 1927911(\mathrm{OR}=1.01,95 \% \mathrm{CI}=0.81-1.28, \mathrm{P}>$ $0.05)$ and $\mathrm{rs} 1927914(\mathrm{OR}=1.19,95 \% \mathrm{CI}=0.94-1.51, \mathrm{P}>0.05)$ failed to show a significant difference (Figure 1).

\section{Haplotype analysis of $T L R 4$ and $T L R 2$ with T2DM}

We identified six types of haplotypes in TLR4 (rs1927914, rs1927911, rs1927907, rs2149356, rs11536889, rs7873784, rs1927906) and five types of haplotypes in TLR2 (rs4696480, rs1898830, rs3804099, rs3804100) with frequencies above $2 \%$. Compared with the haplotype TGTT, the haplotypes AGTT $(\mathrm{OR}=0.34,95 \% \mathrm{CI}=0.15-0.77, \mathrm{P}=0.01)$ and AATT $(\mathrm{OR}=1.20,95 \% \mathrm{CI}=1.01-1.44, \mathrm{P}=0.05)$ in $T L R 2$ were significantly associated with T2DM (Table 5). 
W.H. Huang et al.

Table 4. Association of the toll-like receptor 4 (TLR4) and TLR2 genes with risk of type 2 diabetes mellitus (T2DM).

\begin{tabular}{|c|c|c|c|c|c|}
\hline Gene & Genotype & Case $(\mathrm{N}=552)$ & Control $(\mathrm{N}=552)$ & Adjusted OR $(95 \% \mathrm{CI})^{\mathrm{a}}$ & Adjusted $\mathrm{P}$ value ${ }^{\mathrm{a}}$ \\
\hline \multirow[t]{40}{*}{$T L R 4$} & rs1927914 & & & & \\
\hline & $\mathrm{CC}$ & 68 & 78 & $1.00(\operatorname{Ref})$ & \\
\hline & TT & 216 & 228 & $1.24(0.75-2.06)$ & 0.410 \\
\hline & $\mathrm{CT}$ & 266 & 244 & $1.36(0.83-2.25)$ & 0.220 \\
\hline & $\mathrm{T} / \mathrm{C}$ & $698 / 402$ & $700 / 400$ & $0.99(0.83-1.18)$ & 0.930 \\
\hline & Log-additive & - & - & $1.01(0.85-1.21)$ & 0.900 \\
\hline & rs1927911 & & & & \\
\hline & TT & 68 & 76 & 1.00 (Ref) & \\
\hline & $\mathrm{CC}$ & 216 & 227 & $1.15(0.69-1.92)$ & 0.590 \\
\hline & $\mathrm{TC}$ & 266 & 246 & $1.24(0.75-2.05)$ & 0.400 \\
\hline & $\mathrm{C} / \mathrm{T}$ & $698 / 402$ & $700 / 398$ & $0.98(0.83-1.17)$ & 0.880 \\
\hline & Log-additive & - & - & $1.01(0.85-1.20)$ & 0.900 \\
\hline & rs1927907 & & & & \\
\hline & GG & 331 & 336 & 1.00 (Ref) & \\
\hline & AA & 28 & 26 & $1.89(0.71-5.04)$ & 0.200 \\
\hline & GA & 185 & 186 & $0.99(0.62-1.59)$ & 0.970 \\
\hline & $\mathrm{A} / \mathrm{G}$ & $241 / 847$ & $238 / 858$ & $1.03(0.84-1.26)$ & 0.810 \\
\hline & Log-additive & - & - & $1.02(0.83-1.25)$ & 0.840 \\
\hline & rs2149356 & & & & \\
\hline & $\mathrm{AA}$ & 68 & 80 & 1.00 (Ref) & \\
\hline & $\mathrm{CC}$ & 216 & 228 & $1.20(0.72-2.00)$ & 0.480 \\
\hline & $\mathrm{AC}$ & 263 & 241 & $1.34(0.81-2.22)$ & 0.260 \\
\hline & $\mathrm{C} / \mathrm{A}$ & $695 / 399$ & $697 / 401$ & $1.00(0.84-1.19)$ & 0.980 \\
\hline & Log-additive & - & - & $1.01(0.85-1.20)$ & 0.900 \\
\hline & GG & 306 & 290 & $1.00(\operatorname{Ref})$ & \\
\hline & $\mathrm{CC}$ & 35 & 28 & $1.14(0.58-2.27)$ & 0.700 \\
\hline & $\mathrm{GC}$ & 204 & 232 & $0.87(0.64-1.19)$ & 0.390 \\
\hline & $\mathrm{C} / \mathrm{G}$ & $274 / 816$ & $288 / 812$ & $0.95(0.78-1.15)$ & 0.580 \\
\hline & Log-additive & - & - & $0.93(0.77-1.14)$ & 0.500 \\
\hline & rs7873784 & & & & \\
\hline & $\mathrm{CC}$ & 8 & 2 & $1.00(\operatorname{Ref})$ & \\
\hline & GG & 441 & 444 & $0.09(0.01-0.83)$ & $0.030 *$ \\
\hline & CG & 96 & 100 & $0.08(0.01-0.74)$ & $0.030 *$ \\
\hline & $\mathrm{G} / \mathrm{C}$ & $978 / 112$ & $988 / 104$ & $0.92(0.69-1.22)$ & 0.560 \\
\hline & Log-additive & - & - & $1.10(0.82-1.46)$ & 0.530 \\
\hline & $\begin{array}{l}\text { rs1927906 } \\
\text { AA }\end{array}$ & 495 & 497 & 1.00 (Ref) & \\
\hline & GG & 2 & 1 & $2.02(0.12-34.79)$ & 0.630 \\
\hline & AG & 53 & 55 & $0.87(0.51-1.49)$ & 0.620 \\
\hline & $\mathrm{G} / \mathrm{A}$ & $57 / 1043$ & $57 / 1049$ & $1.01(0.69-1.47)$ & 0.980 \\
\hline & Log-additive & - & - & $1.00(0.69-1.46)$ & 0.990 \\
\hline \multirow{24}{*}{$T L R 2$} & rs 1898830 & & & & \\
\hline & AA & 195 & 151 & 1.00 (Ref) & \\
\hline & $\mathrm{AG}$ & 241 & 249 & $0.67(0.46-0.97)$ & $0.038 *$ \\
\hline & GG & 96 & 115 & $0.70(0.45-1.10)$ & 0.129 \\
\hline & $\mathrm{G} / \mathrm{A}$ & $433 / 631$ & $479 / 551$ & $0.88(0.79-0.97)$ & $0.007 *$ \\
\hline & Log-additive & - & - & $0.78(0.67-0.95)$ & $0.009^{*}$ \\
\hline & rs3804099 & & & & \\
\hline & TT & 289 & 279 & 1.00 (Ref) & \\
\hline & $\mathrm{TC}$ & 205 & 229 & $0.82(0.60-1.14)$ & 0.247 \\
\hline & $\mathrm{CC}$ & 43 & 34 & $1.17(0.63-2.16)$ & 0.602 \\
\hline & $\mathrm{C} / \mathrm{T}$ & $291 / 783$ & $297 / 787$ & $0.99(0.86-1.14)$ & 0.874 \\
\hline & Log-additive & - & - & $0.98(0.81-1.19)$ & 0.873 \\
\hline & rs4696480 & & & & \\
\hline & TT & 97 & 93 & 1.00 (Ref) & \\
\hline & TA & 258 & 294 & $0.81(0.53-1.23)$ & 0.328 \\
\hline & AA & 190 & 158 & $1.10(0.70-1.73)$ & 0.675 \\
\hline & $\mathrm{A} / \mathrm{T}$ & $638 / 452$ & $610 / 480$ & $1.06(0.97-1.13)$ & 0.225 \\
\hline & Log-additive & - & - & $0.90(0.75-1.07)$ & 0.220 \\
\hline & rs 3804100 & & & & \\
\hline & TT & 316 & 315 & 1.00 (Ref) & \\
\hline & $\mathrm{TC}$ & 193 & 208 & $0.88(0.64-1.20)$ & 0.427 \\
\hline & $\mathrm{CC}$ & 35 & 28 & $1.10(0.56-2.18)$ & 0.765 \\
\hline & $\mathrm{C} / \mathrm{T}$ & $263 / 825$ & $264 / 838$ & $1.00(0.87-1.17)$ & 0.906 \\
\hline & Log-additive & - & - & $1.01(0.83-1.23)$ & 0.910 \\
\hline
\end{tabular}

${ }^{a}$ Adjusted for age, gender, and body mass index (BMI). $* \mathrm{P}<0.05$. 


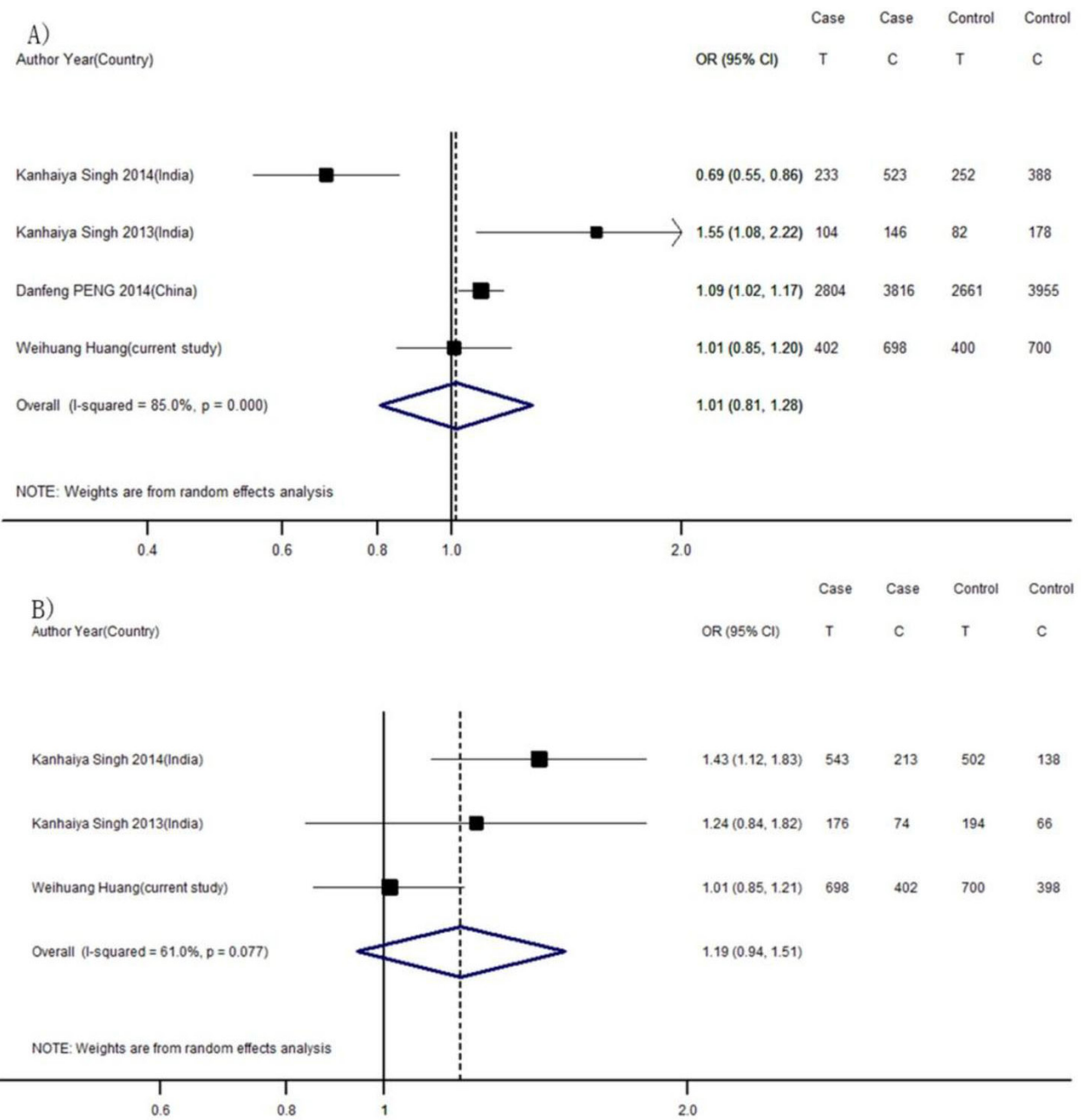

Figure 1. Forest plot of toll-like receptor 4 gene (TLR4) polymorphisms and type 2 diabetes mellitus (T2DM) risk. A. Pooled OR of rs1927911 for T versus C; B. Pooled OR of rs1927914 for C versus T.

Table 5. Association of haplotypes with type 2 diabetes mellitus (T2DM).

\begin{tabular}{llcccc}
\hline Gene & Haplotype & Case & Control & OR & P value \\
\hline TLR4 & TCGCGGA & 38.2 & 37.0 & $1.05(0.89-1.25)$ & 0.569 \\
& TCGCCGA & 24.9 & 26.0 & $0.95(0.78-1.15)$ & 0.572 \\
& CTAAGGA & 17.2 & 16.6 & $1.12(0.84-1.31)$ & 0.705 \\
& CTGAGCA & 10.1 & 9.1 & $0.99(0.68-1.46)$ & 0.417 \\
& CTAAGGG & 5.0 & 5.0 & $0.79(0.53-1.18)$ & 0.998 \\
$T L R 2$ & CTGAGGA & 4.0 & 5.0 & $0.87(0.74-1.04)$ & 0.244 \\
& TGTT & 39.3 & 2.7 & $1.20(1.01-1.44)$ & $0.050^{*}$ \\
& AATT & 30.7 & 22.1 & $1.01(0.83-1.24)$ & 0.900 \\
& AACC & 3.9 & 3.3 & $1.20(0.77-1.89)$ & 0.418 \\
& AACT & 0.7 & 2.1 & $0.34(0.15-0.77)$ & $0.007^{*}$ \\
\hline
\end{tabular}

$* \mathrm{P}<0.05$. 


\section{DISCUSSION}

We presented evidence for associations between non-missense polymorphisms located in the regulatory regions of TLR4 and TLR2 genes and the risk of T2DM in a southern Chinese population. We identified SNP rs7873784 in TLR4 and SNP rs1898830 in TLR2 as being significantly associated with T2DM risk in the Chinese population.

The 3'-UTR SNP rs7873784 appeared to be the significant locus associated with T2DM in the Chinese population. The homogeneous genotype CC of rs7873784 was a risk factor for T2DM. The allele $\mathrm{C}$ frequency of rs 7873784 was $9.9 \%$ in our study, which is less than the $14.6 \%$ found in the CEU population (Utah residents with ancestry from northern and Western Europe) and the $27.8 \%$ found in the YRI population (Yoruba in Ibadan, Nigeria) based on the data from the HapMap project. To our knowledge, the effect of rs7873784 variation on T2DM has not been described in a case-control study before, although one case-cohort study on rs7873784 found no direct association with the incidence of T2DM (Kolz et al., 2008). Chen et al. (2005) reported that the CC and CG genotypes in rs 7873784 were associated with a decrease in prostate cancer risk in a US population. Bertinetto et al. (2012) reported that the $\mathrm{G}$ allele and the GG genotype were associated with IgA nephropathy with proteinuria for rs7873784 in TLR4 in a north Italian population. Transcriptional regulation is also changed when the allele in rs7873784 is changed from $\mathrm{C}$ to $\mathrm{G}$, and transcription factor STATx cannot bind to the TLR4 gene, as predicted by the transcription factor search tool. Combined with above reports, the current study implies that 3'-UTR rs7873784 might play a role in the development of T2DM, and seems to be a good candidate for a functional SNP.

We also suggest that rs1898830 (AG) and rs1898830 (G) are a "protective" genotype and allele, respectively. Until now, there has been no research on the relationship between $T L R 2$ rs 1898830 and susceptibility to T2DM. However, the TLR2 polymorphism rs 1898830 has been associated with maternal atopy, bronchiolitis obliterans, and pulmonary tuberculosis in previous studies (Chen et al., 2010; Kastelijn et al., 2010; Liu et al., 2011). rs1898830, which is located in the intron region of TLR2, can cause the decline of lung function in cystic fibrosis patients (Haerynck et al., 2013). Moreover, Taniguchi et al. (2013) have reported that the genotype AG in rs1898830 is associated with congenital cytomegalovirus infection. Liu et al. (2011) found that the GG genotype of rs1898830 in combination with maternal atopy leads to a decrease in regulatory $\mathrm{T}$ cell markers, indirectly pointing to potentially insufficient immunosuppression. In addition, Chen et al. (2011) suggest that rs1898830 is associated with TLR2-mediated cellular activation, which is caused by the effect of rs13150331 on transcriptional activities of the TLR2 gene promoter. Variation of the gene promoter may affect mRNA transcription efficiency, stability, translation, etc. The mechanism by which TLR2 takes effect may be partly based on the above evidence, although it requires further clarification. We supposed that after being stimulated by high glucose and free fatty acids (Ehses et al., 2010), TLR2 with genotype rs 1898830 (AA) was more likely to induce the expression of IKK- $\beta$ and NF- $\kappa B$ pathway target genes, and also facilitated secretion of pro-inflammatory cytokines and chemokines, including TNF, IL-6, IL-1 $\beta$, CCL2, and CCL3 (Cai et al., 2005; Donath and Shoelson, 2011). These factors can induce the aggregation of inflammatory cells, promoting inflammation in islet, adipose, and liver tissues, and resulting in insulin resistance and ultimately the development of T2DM (Donath and Shoelson, 2011). However, there exists another possibility that the intron region of DNA could regulate the expression of genes through circular RNA (Zhang et al., 2013). Thus, variations at the intron could contribute to 
the function of DNA. However, more investigation is required to elucidate the underlying mechanism of this effect.

For the other nine loci, none of the genotypes showed any significant association with T2DM in the southern Chinese population. Unfortunately, the SNPs rs 1927911, rs1927907, rs 11536889 , rs 1927906 , rs 3804099 , and rs3804100 with negative results lacked the genetic power (lower than $80 \%$ ) to detect the true "causal" associations. Further, we performed metaanalyses on rs1927911 and rs1927914 but did not find any associations. The sample size was not large enough to detect associations and there was high heterogeneity among the studies included. Therefore, more studies are required.

With regards to haplotype analysis, compared with the control subjects, the frequency of the AATT haplotype was higher in T2DM subjects, suggesting that haplotype AATT was associated with increasing T2DM susceptibility. In contrast, the AGTT haplotype was associated with lower risk of disease susceptibility. As we expected, the AGTT and AATT haplotypes differed only in the rs1898830 (A/G) allele, which indicates that rs1898830 (A/G) influences the effects of the haplotypes on the risk of T2DM. However, estimation of the haplotype was based on statistical calculation without biological evidence. Thus, further analysis of the underlying mechanisms of TLR2 haplotype contribution to T2DM susceptibility is needed.

In conclusion, we have provided evidence that polymorphisms in TLR 4 and TLR2 are associated with T2DM. The genotypes GG and CG of 3'-UTR SNP rs7873784, and the genotype AG and allele $\mathrm{G}$ of intron SNP rs 1898830 protected against the development of T2DM in southern Chinese people. In addition, haplotypes AATT and AGTT were significantly associated with susceptibility to T2DM. Although the variant at 3'-UTR in TLR4 decreases the stability of the TLR 4 mRNA according to other studies, the exact functional effect of rs 7873784 on the expression of TLR4 still requires further investigation.

\section{Conflicts of interest}

The authors declare no conflict of interest.

\section{ACKNOWLEDGMENTS}

Research supported in part by the National Natural Science Foundation of China (grant \#30901249 and \#81101267), the Guangdong Natural Science Foundation (grant \#10151063201000036 and \#S2011010002526), and a project grant from Jinan University (grant \#21612426).

\section{REFERENCES}

Bagarolli RA, Saad MJ and Saad ST (2010). Toll-like receptor 4 and inducible nitric oxide synthase gene polymorphisms are associated with Type 2 diabetes. J. Diab. Compl. 24: 192-198.

Barrett JC, Fry B, Maller J and Daly MJ (2005). Haploview: analysis and visualization of LD and haplotype maps. Bioinformatics 21: 263-265.

Bertinetto FE, Calafell F, Roggero S, Chidichimo R, et al. (2012). Search for genetic association between IgA nephropathy and candidate genes selected by function or by gene mapping at loci IGAN2 and IGAN3. Nephrol. Dial. Transplant. 27: 2328-2337.

Buraczynska M, Baranowicz-Gaszczyk I, Tarach J and Ksiazek A (2009). Toll-like receptor 4 gene polymorphism and early onset of diabetic retinopathy in patients with type 2 diabetes. Hum. Immunol. 70: 121-124.

Cai D, Yuan M, Frantz DF, Melendez PA, et al. (2005). Local and systemic insulin resistance resulting from hepatic activation of IKK-beta and NF-kappaB. Nat. Med. 11: 183-190. 
Caricilli AM, Nascimento PH, Pauli JR, Tsukumo DM, et al. (2008). Inhibition of toll-like receptor 2 expression improves insulin sensitivity and signaling in muscle and white adipose tissue of mice fed a high-fat diet. J. Endocrinol. 199: 399-406.

Chen KH, Gu W, Zeng L, Jiang DP, et al. (2011). Identification of haplotype tag SNPs within the entire TLR2 gene and their clinical relevance in patients with major trauma. Shock 35: 35-41.

Chen YC, Giovannucci E, Lazarus R, Kraft P, et al. (2005). Sequence variants of Toll-like receptor 4 and susceptibility to prostate cancer. Cancer Res. 65: 11771-11778.

Chen YC, Hsiao CC, Chen CJ, Chin CH, et al. (2010). Toll-like receptor 2 gene polymorphisms, pulmonary tuberculosis, and natural killer cell counts. BMC Med. Genet. 11: 17.

Creely SJ, McTernan PG, Kusminski CM, Fisher fM, et al. (2007). Lipopolysaccharide activates an innate immune system response in human adipose tissue in obesity and type 2 diabetes. Am. J. Physiol. Endocrinol. Metab. 292: E740-E747.

Dasu MR, Devaraj S, Zhao L, Hwang DH, et al. (2008). High glucose induces toll-like receptor expression in human monocytes: mechanism of activation. Diabetes 57: 3090-3098.

Dasu MR, Devaraj S, Park S and Jialal I (2010). Increased toll-like receptor (TLR) activation and TLR ligands in recently diagnosed type 2 diabetic subjects. Diabetes Care 33: 861-868.

Donath MY and Shoelson SE (2011). Type 2 diabetes as an inflammatory disease. Nat. Rev. Immunol. 11: 98-107.

Ehses JA, Meier DT, Wueest S, Rytka J, et al. (2010). Toll-like receptor 2-deficient mice are protected from insulin resistance and beta cell dysfunction induced by a high-fat diet. Diabetologia 53: 1795-1806.

Genuth S, Alberti KG, Bennett P, Buse J, et al. (2003). Follow-up report on the diagnosis of diabetes mellitus. Diabetes Care 26: 3160-3167.

Haerynck F, Mahachie John JM, Van Steen K, Schelstraete P, et al. (2013). Genetic variations in toll-like receptor pathway and lung function decline in Cystic fibrosis patients. Hum. Immunol. 74: 1649-1655.

Hotamisligil GS (2006). Inflammation and metabolic disorders. Nature 444: 860-867.

Illig T, Bongardt F, Schöpfer A, Holle R, et al. (2003). The endotoxin receptor TLR4 polymorphism is not associated with diabetes or components of the metabolic syndrome. Diabetes 52: 2861-2864.

Jiang ZS, Wang SX, Jia HX, Wang J, et al. (2013). Association of toll-like receptor 4 polymorphisms with type 2 diabetes mellitus. Inflammation 36: 251-257.

Kastelijn EA, van Moorsel CH, Rijkers GT, Ruven HJ, et al. (2010). Polymorphisms in innate immunity genes associated with development of bronchiolitis obliterans after lung transplantation. J. Heart. Lung. Transplant. 29: 665-671.

Kolz M, Baumert J, Müller M, Khuseyinova N, et al. (2008). Association between variations in the TLR4 gene and incident type 2 diabetes is modified by the ratio of total cholesterol to HDL-cholesterol. BMC Med. Genet. 9: 9.

Kumar, V, Abbas, AK., Fausto, N, Aster, JC (2014). Robbins and cotran pathologic basis of disease, Professional Edition: Expert Consult-Online. Elsevier Health Sciences.

Kuo LH, Tsai PJ, Jiang MJ, Chuang YL, et al. (2011). Toll-like receptor 2 deficiency improves insulin sensitivity and hepatic insulin signalling in the mouse. Diabetologia 54: 168-179.

Liu F, Lu W, Qian Q, Qi W, et al. (2012). Frequency of TLR 2, 4, and 9 gene polymorphisms in Chinese population and their susceptibility to type 2 diabetes and coronary artery disease. J. Biomed. Biotechnol. 2012: 373945.

Liu J, Rädler D, Illi S, Klucker E, et al. (2011). TLR2 polymorphisms influence neonatal regulatory T cells depending on maternal atopy. Allergy 66: 1020-1029.

Maldonado-Bernal C, Trejo-de la O A, Sánchez-Contreras ME, Wacher-Rodarte N, et al. (2011). Low frequency of Tolllike receptors 2 and 4 gene polymorphisms in Mexican patients and their association with type 2 diabetes. Int. J. Immunogenet. 38: 519-523.

Miller YI, Viriyakosol S, Worrall DS, Boullier A, et al. (2005). Toll-like receptor 4-dependent and -independent cytokine secretion induced by minimally oxidized low-density lipoprotein in macrophages. Arterioscler. Thromb. Vasc. Biol. 25: 1213-1219.

Noreen M, Shah MA, Mall SM, Choudhary S, et al. (2012). TLR4 polymorphisms and disease susceptibility. Inflamm. Res. 61: 177-188.

Park JS, Gamboni-Robertson F, He Q, Svetkauskaite D, et al. (2006). High mobility group box 1 protein interacts with multiple Toll-like receptors. Am. J. Physiol. Cell Physiol. 290: C917-C924.

Peng D, Jiang F, Zhang R, Tang S, et al. (2014). Association of Toll-like Receptor 4 Gene polymorphisms with susceptibility to type 2 diabetes mellitus in the Chinese population. J. Diabetes. doi: 10.1111/1753-0407.12206.

Pickup JC (2004). Inflammation and activated innate immunity in the pathogenesis of type 2 diabetes. Diabetes Care 27: 813-823.

Singh K, Singh VK, Agrawal NK, Gupta SK, et al. (2013). Association of Toll-like receptor 4 polymorphisms with diabetic foot ulcers and application of artificial neural network in DFU risk assessment in type 2 diabetes patients. 
Biomed. Res. Int. 2013: 318686.

Singh K, Kant S, Singh VK, Agrawal NK, et al. (2014). Toll-like receptor 4 polymorphisms and their haplotypes modulate the risk of developing diabetic retinopathy in type 2 diabetes patients. Mol. Vis. 20: 704-713.

Taniguchi R, Koyano S, Suzutani T, Goishi K, et al. (2013). Polymorphisms in TLR-2 are associated with congenital cytomegalovirus (CMV) infection but not with congenital CMV disease. Int. J. Infect. Dis. 17: e1092-e1097.

Wong FS and Wen L (2008). Toll-like receptors and diabetes. Ann. N. Y. Acad. Sci. 1150: 123-132.

Yang CS, Shin DM, Lee HM, Son JW, et al. (2008). ASK1-p38 MAPK-p47phox activation is essential for inflammatory responses during tuberculosis via TLR2-ROS signalling. Cell Microbiol. 10: 741-754.

Yang W, Lu J, Weng J, Jia W, et al. (2010). Prevalence of diabetes among men and women in China. N. Engl. J. Med. 362: 1090-1101.

Yin J, Peng Y, Wu J, Wang Y, et al. (2014). Toll-like receptor 2/4 links to free fatty acid-induced inflammation and $\beta$-cell dysfunction. J. Leukoc. Biol. 95: 47-52.

Zhang Y, Zhang XO, Chen T, Xiang JF, et al. (2013). Circular intronic long noncoding RNAs. Mol. Cell 51: 792-806. 